\title{
САМОПРЕЗЕНТАЦИЯ ПЕДАГОГА В ПРОФЕССИОНАЛЬНОЙ ДЕЯТЕЛЬНОСТИ
}

\author{
C.В. Карев \\ Московский Городской педагогический университет \\ К.В. Петрунина \\ Московский гуманитарный университет
}

\begin{abstract}
Аннотация: В статье представлена краткая характеристика основных теоретических подходов к изучению феномена «самопрезентачия» и существующих наиболее эффрективных методик и техник обучения самопрезентаци; показана значимость самопрезентации в профессиональной деятельности.
\end{abstract}

Ключевые слова: самопрезентация; обучение самопрезентации; самопрезентация педагога; имидж

\section{SELF-PRESENTATION OF A TEACHER IN PROFESSIONAL ACTIVITIES}

\author{
S.V. Karev \\ Moscow City Pedagogical University \\ K.V. Petrunina \\ Moscow University for the Humanities
}

\begin{abstract}
The article presents a brief description of the main theoretical approaches to the study of the phenomenon of "self-presentation» and the existing most effective methods and techniques of teaching self-presentation; shows the importance of self-presentation in professional activities.
\end{abstract}

Keywords: self-presentation; self-presentation training; self-presentation of the teacher; image

Родоначальником понятия «самопрезентация» является И. Гофман, американский социолог и психолог. В работе «Представление себя другим в повседневной жизни» он создал теорию социальной драматургии, в рамках которой впервые описал процесс самопрезентации. Согласно его теории, человек в процессе социального взаимодействия старается производить нужное впечатление о себе для достижения определенных целей, например, для поддержания своего социального статуса. Способность человека к самовыражению содержит два совершенно разных вида знаковой активности. Первый вид связан с произвольным самовыражением, в процессе которого человек представляет информацию о себе. Второй вид знаковой активности - непроизвольное самовыражение, в процессе которого человек непроизвольно «выдает сам себя». В процессе различных коммуникативных действий человек ведет себя как актер, который создает свой собственный, непредсказуемый образ. Конкретная коммуникативная ситуация в теории И. Гофмана названа сценой. Любая активность человека, оказывающая влияние на зрителей, когда он предстает непосредственно перед ними обозначается термином «исполнение» (Гофман, 2000: 33). 
На данный момент существует множество теорий самопрезентации. Е.В. Михайлова в своем пособии «Обучение самопрезентации» разделяет различные теоретические подходы на три группы.

Первая группа - мотивационные теории, «...самопрезентация здесь определяется внутренними факторами. По мнению А. Адлера, побуждения, лежащие в основе самопрезентации, - это стремление к превосходству, по мнению Р. Харе - это потребность в уважении. И. Джонс и Т. Питтман считали, что в основе самопрезентации лежит мотив власти» (Михайлова, 2006: 44).

Вторую группу составляют ситуативные теории. Самопрезентация определяется внешними условиями конкретной ситуации, в которой находится человек (этнокультурная принадлежность, регион проживания, гендерная принадлежность и т.д.). Дж. Тедеши и М. Риес определяют самопрезентацию как намеренный, осознаваемый процесс, направленный на создание определенного впечатления у окружающих, в зависимости от общественных норм и ценностей, в которых самопрезентация реализуется. По мнению Р. Баумейстеру и А. Стейхилберу, самопрезентация это самораскрытие в межличностном общении через демонстрацию своих мыслей, характера и т.д. (Там же: 45);

Сторонники теорий третьей группы считают, что на самопрезентацию оказывают влияние и внутренние, и внешние условия. Сторонники этой теории М. Лири и Р. Ковальски определяют самопрезентацию как «...процесс, посредством которого индивиды пытаются контролировать впечатления окружающих о них самих» (Шкуратова, 2009: 16). Они разработали теоретическую модель самопрезентации, содержащую два блока: мотивационный (побуждения, стремления, цели управления впечатлением) и конструктивный (текущая социальная роль, ценности людей, на которых направлен образ) (Там же).

Для достижения успеха особенно в ситуациях социальной и конкурентоспособной личности выступает способность как можно эффективнее презентовать свои личностные качества. Поэтому обучение студентов навыкам самопрезентации является одной из важнейших задач процесса обучения в вузе (Казаченок, 2016: 101).

Ориентирование студента на успешную самопрезентацию реализуется с помощью совокупности социально-педагогических условий, методов и средств, направленных на получение знаний о самопрезентации, умений производить нужное впечатление, навыков построения и ведения беседы и т.п. (Там же: 102).

В психолого-педагогической научной литературе имеется большое количество работ, посвященных навыкам обучения студентов различным технологиям самопрезентации.

Методам обучения самопрезентации посвящена работа Е.В. Михайловой «Обучение самопрезентации», в которой она рассматривает существующие наиболее эффективные методики. Исследователи И. Джонс и Т. Питтман были одними из первых разработчиков стратегий самопрезентации, которые основаны на целях и тактиках, используемых людьми в общении с окружающими. Они утверждали, что 
Научные труды Московского гуманитарного университета

2020 № 4

самопрезентация очень важна для человека, который использует различные источники власти, тем самым поддерживая и расширяя свое влияние в различных межличностных отношениях.

На первое место ученые ставят стратегию, связанную со стремлением понравиться. Для этого человеку необходимо проявлять такие личностные качества как доброжелательность, угождение другим, что, в конечном итоге, позволяет ему достичь «власти обаяния».

Вторая стратегия связана с саморекламой, показывающая умение рекламировать себя, свои знания, способности, проявляющиеся в той или иной сфере, свою компетентность, что в итоге проявляется во власти эксперта.

Третья стратегия связана с демонстрацией духовного превосходства, с желанием и стремлением быть примером для других, что в результате дает власть наставника.

Четвертая стратегия - запугивание, направлена на демонстрацию силы, на желание подчинить себе окружающих, что в результате выливается во власть страха.

Пятая стратегия, как противоположность предыдущей связана с демонстрацией слабости и характеризует власть сострадания (Михайлова, 2006: 128).

Американский психолог Р. Чалдини разработал две техники самопрезентации, связанные с управлением впечатлением. Первая техника связана с наслаждением отраженной славы и в целях своей самопрезентации направлена на использование чужого успеха. Вторая техника, наоборот, нацелена на намеренное преувеличение своего статуса в окружающей среде и ставит своей целью вредить (Там же: 130).

Существует так называемая «техника самоподачи», суть которой заключается в умении целенаправленно привлечь внимание кого-либо с специально и намеренно созданными особенностями своего внешнего облика, образа. Все это направлено на соответствующее социальное восприятие человека партнером по взаимодействию. Г.В. Бороздина выделяет такие техники самоподачи как «самоподача превосходства» (превосходство, отраженное в поведении, манере речи, в особенностях одежды); «самоподача привлекательности» («попытка» гармонизировать внешние данные и одежду, например); «самоподача отношения» (взаимодействие с окружающими с использованием различных вербальных и невербальных средств); «самоподача состояние и причин поведения» (привлечение внимания собственных действий, кажущихся субъекту наиболее приемлемыми) (Там же: 131).

Е.В. Михайлова предлагает обучение самопрезентации проводить путем социально-психологического тренинга (в группе) или в индивидуальном консультировании (индивидуально). Социально-психологический тренинг чаще всего подразумевает под собой повышение коммуникативной компетентности, так как коммуникация - это неотъемлемая часть процесса самопрезентации, от которой во многом зависит уровень успешной самопрезентации. Индивидуальное обучение строится в форме консультаций с последующим выполнением заданий в реальных или смоделированных условиях (Михайлова, 2006). 
Работа Дмитриевой Ж.Р. «Социально-психологическое обеспечение планирования карьеры молодых специалистов» посвящена разработке социально-психологического тренинга «Карьерная самопрезентация», который состоит из нескольких блоков - информационного, технологического и итогового. Каждый из представленных блоков направлен, с одной стороны, - на развитие навыков самопрезентации, с другой, - направлен на управление впечатлением о себе и отрабатывается на основе использования различных групповых методов обучения, таких как ролевые игры, групповые дискуссии, видеоанализ (Дмитриева, 2011).

Иную модель и технологию формирования готовности к самопрезентационной деятельности студентов разработала Карасева С.А. в работе «Формирование готовности будущих бакалавров-менеджеров к самопрезентационной деятельности». Цель разработанной модели - освоение студентами алгоритма самопрезентационной деятельности. Алгоритм представлен четырьмя последовательными шагами: моделирование самопрезентации; реализация модели самопрезентации; анализ результатов самопрезентации; коррекция модели и её реализация (Карасева, Гонежук, 2013).

Понятие самопрезентации также тесно взаимосвязано с таким важным понятием как имидж. Имидж дает устойчивое представление об особенностях какого-либо явления или личности человека. Если речь идет о личности человека, то имидж может отражать результаты его труда, его достижения, профессиональные навыки (Карасева, Хазова, 2012: 59). Так, например, для завоевания авторитета у обучаемых, у своих коллег, у руководства и т.д. современному педагогу требуется работать над собственным имиджем для формирования своей уникальной самопрезентации (Шамсиддинова, 2019: 46).

Педагог, умеющий эффективно налаживать сотрудничество и эффективно взаимодействовать, располагает к себе всех участников образовательного процесса. Умение быстро адаптироваться в любой обстановке упрощает установление коммуникативных связей со студентами и повышает возможность воздействия на них (Федосова, 2014: 118).

Для достижений целей важно научиться управлять впечатлением, необходимо не только обладать особыми качествами, умениями и способностями, но и правильно их преподнести и правильно подать.

Таким образом, представленный анализ некоторых основных теорий самопрезентации и методик их воплощения в реальной жизни позволяет убедиться в их важной роли в процессе профессиональной подготовки специалиста любого профиля. Что же касается педагогической деятельности, то знание существующих техник, приемов и различных методик самопрезентации позволит будущему специалисту сферы образования сформировать свой адекватный имидж, что несомненно отразится на качестве и результативности образовательного процесса, независимо от уровня образовательной организации. 


\section{СПИСОК ЛИТЕРАТУРЫ}

Гофман, И. (2000) Представление себя другим в повседневной жизни / Пер. с англ. и вступ. Статья А.Д. Ковалева - М.: КАНОН-пресс-Ц, Кучково поле. - 304 с.

Дмитриева, Ж.Р. (2011) Социально-психологический тренинг как средство развития карьерных компетенций // Вестник университета (Государственный университет управления). - М.: ГУУ. №8. С.36-38.

Казаченок, Ю.В. (2016) К вопросу об активизации самопрезентационной деятельности студентов как продуктивной педагогической стратегии // Вестник Омского государственного педагогического университета. Гуманитарные исследования. №2 (11). C. 101-103.

Карасева, С.А., Гонежук, А.Г. (2013) Формирование готовности студентов к самопрезентационной деятельности в процессе профессиональной подготовки // Глобальный научный потенциал. Вып. 8 (29). Серия Профессиональное образование. Тамбов: Фонд развития науки и культуры. С.20-22.

Карасева, С.А., Хазова, С.А. (2012) Самопрезентационная компетентность современного конкурентоспособного специалиста // Вестник Адыгейского государственного университета. Серия 3: Педагогика и психология. №4 (109). C. 55-64.

Михайлова, Е.В. (2006) Обучение самопрезентации: учебное пособие / Е. В. Михайлова. М.: ГУ ВШЭ. 166 с.

Федосова, И.В. (2014) Профессиональный имидж педагога в контексте личностно-профессиональной подготовки будущего специалиста сферы образования // Психология в экономике и управлении. №1. С. 117-120.

Шамсиддинова, Э.М., (2019) Самопрезентация и эффективная коммуникация как базовые компетенции педагога // Наука, образование и культура. №1 (35). C. 46-47.

Шкуратова, И.П. (2009) Самопредъявление личности в общении: монография / И.П. Шкуратова. - Ростов-на-Дону: ЮФУ. 192 с.

Карев Сергей Викторович - магистрант института педагогики и психологии образования Московского городского педагогического университета. Научный руководитель - д-р пед. н., профессор В.А. Ситаров. Адрес: 129226, Россия, Москва, 2-й Сельскохозяйственный проезд, 4. Тел.: +7 (499) 181-24-62. Эл. адрес: s.karev@ok654.ru.

Karev Sergei Viktorovich, Graduate Student, Department of Pedagogy, Moscow City Pedagogical University. Scientific Adviser - V.A. Sitarov, Doctor of Pedagogy, Professor. Postal address: 4, 2nd Agricultural passage, Moscow, Russian Federation, 129226. Tel.: +7 (499) 181-24-62. E-mail: s.karev@ok654.ru

Петрунина Ксения Викторовна - магистрант кафедры педагогики и психологии высшей школы Московского гуманитарного университета. Научный руково- 
дитель - канд. псих. н., доцент Е.Е. Иванова. Адрес: 111395, Россия, г. Москва, ул. Юности, д. 5. Тел.: +7 (499) 374-74-59. Эл. адрес: kpetrunina96@mail.ru.

Petrunina Kseniya Victorovna, Graduate Student, Department of Pedagogyand Psychology of Higher School, Moscow University for the Humanities. Scientific Adviser - E.E.Ivanova Candidate of Psychological Sciences, Docent. Postal address: 5, Yunosti St., Moscow, Russian Federation, 111395. Tel.: +7(499) 374-74-59. E-mail: kpetrunina96@mail.ru.

Карев С.В., Петрунина К.В. Самопрезентация педагога в профессиональной деятельности // Научные труды Московского гуманитарного университета. 2020. №4. С. 42-47. DOI: https://www.doi.org/10.17805/trudy.2020.4.6 